\title{
The Effect of Premature Delivery on the Development of Gluconeogenic Enzymes in the Guinea Pig
}

\author{
BRIAN H. ROBINSON(28) AND JOS OEI \\ Departments of Paediatrics and Biochemistry, University of Toronto, and Research Institute, \\ The Hospital for Sick Children, Toronto, Ontario, Canada
}

\section{Extract}

The activities of key gluconeogenic enzymes in the livers of newborn guinea pigs were monitored as a function of time following birth either vaginally at term or prematurely by cesarian section at 62 days of gestation. The activity of hepatic glucose-6-phosphatase rose dramatically from $1.40 \pm 0.26 \mu \mathrm{mol} / \mathrm{min} / \mathrm{g}$ at birth to a maximum of $6.8 \pm 0.9 \mu \mathrm{mol} / \mathrm{min} / \mathrm{g}$ at $24 \mathrm{hr}$ in prematurely delivered animals although there was little significant change in activity in full term animals. The activity of hepatic fructose-1,6diphosphatase and mitochondrial phosphoenolpyruvate carboxykinase changed little over the first $\mathbf{3}$ days of life in either full term or premature animals. Cytosolic phosphoenolpyruvate carboxykinase, on the other hand, had low activity at birth being $0.11 \pm 0.03$ $\mu \mathrm{mol} / \mathrm{min} / \mathrm{g}$ in full term and $0.06 \pm 0.04 \mu \mathrm{mol}$ in premature animals rising to values of $0.71 \pm 0.06$ and $1.12 \pm 0.12 \mu \mathrm{mol} / \mathrm{min} / \mathrm{g}$, respectively, at $24 \mathrm{hr}$ of life. Pyruvate carboxylase activities in the premature animals remained significantly lower than those in full term animals in the first $72 \mathrm{hr}$ of life. Transient hypoglycemia was evident in the prematurely delivered animals, but not in the full term animals, the blood glucose values being $82 \pm 7 \mathrm{mg} / 100 \mathrm{ml}$ for the full term animals and $20 \pm 8 \mathrm{mg} / 100 \mathrm{ml}$ for the premature infants at $2 \mathrm{hr}$ of life.

\section{Speculation}

Premature delivery of the newborn guinea pig leads to neonatal hypoglycemia which is due to a combination of deficient hepatic glycogen and compromised gluconeogenic enzyme activity.

In a recent publication, we were able to show that the full term newborn guinea pig did not develop postnatal hypoglycemia as is seen in the newborn rat (17). It was postulated at that time that the presence of mitochondrial phosphoenolpyruvate carboxykinase at birth in these animals enabled the gluconeogenic pathway to function adequately, compared with the situation in the rat where there is a virtual absence of phosphoenolpyruvate carboxykinase in the mitochondrial compartment $(2,20)$. Both of these species have low activities of cytosolic phosphoenolpyruvate carboxykinase at birth $(3,12,17)$, a situation which in the rat has been thought to be responsible for the low rates of gluconeogenesis seen in these animals (3). However, induction of cytosolic phosphoenolpyruvate carboxykinase by prenatal treatment with progesterone failed to prevent postnatal hypoglycemia in newborn rats (12). In this communication we investigate the effect of premature delivery on the glycemic status, on the development of gluconeogenic enzymes, and on the gluconeogenic capacity of newborn guinea pigs.

\section{MATERIALS AND METHODS}

\section{CHEMICALS}

Special chemicals, intermediates, and coenzymes were obtained from the Sigma Chemical Co., St. Louis, Mo. Enzymes were purchased from Boehringer-Mannheim Corporation (Quebec City). Radioactive intermediates were obtained from AmershamSearle (Toronto).

\section{ANIMALS}

Pregnant guinea pigs were purchased from High Oak Ranch, Ltd., Toronto, as timed pregnancies at 60 days of gestation. In the control group, birth was allowed to proceed naturally at term (65-68 days) and the newborn animals remained with the mother until the time they were killed. Another group of neonates was delivered at 62 days of gestation by cesarian section under light anesthesia; the mother was killed postoperatively. The newborn animals were given immediately to foster mothers who had given birth naturally 1 or 2 days previously and had been deprived of their offspring. It was judged by stomach contents and by observation that this second group were fed by their foster mothers. Both groups were observed to be feeding and drinking independently of the mothers by 3 days postpartum.

\section{ENZYME ASSAYS}

Samples of liver taken at time of death were blotted, weighed, and then homogenized in 10 volumes of an ice-cold buffer containing $0.25 \mathrm{M}$ sucrose, $5 \mathrm{mM}$ Tris- $\mathrm{HCl}$, and $0.1 \mathrm{mM}$ EGTA, $\mathrm{pH}$ 7.4. The resulting homogenate was centrifuged at $600 \times g$ for 10 min to remove cell debris and the supernatant from this step was then centrifuged at $12,000 \times g$ for 10 min to give fractions containing $(I)$ the mitochondrial pellet and $(2)$ the microsomes plus the soluble components of the cells. Fructose-1,6-diphosphatase was measured by the method of Pontremoli (14), glucose-6phosphatase by the method of Swanson (21), and pyruvate carboxylase by the method of Crabtree et al. (7). Phosphoenolpyruvate carboxykinase was measured by the method of Roobol and Alleyne (18), mitochondria being solubilized for the determination by the addition of $0.1 \%$ Triton X-100 to the assay system. Phosphoenolpyruvate carboxykinase activity is not affected by the presence of Triton X-100 (16). All activities were measured at $37^{\circ}$. Blood glucose was measured by the method of Slein (19) in blood samples collected at the time of death and liver glycogen by the same method after alkaline extraction of the tissue followed by alcohol precipitation and hydrolysis of glycogen into glucose.

\section{RADIOISOTOPE INCORPORATION EXPERIMENTS}

Animals matched for weight and glycemic state were injected intraperitoneally at the time following birth stated with a combined dose of $2 \mu \mathrm{Ci} \mathrm{L}-\left[U-{ }^{14} \mathrm{C}\right]$ lactic acid and $2 \mu \mathrm{Ci}$ D-[2$\left.{ }^{3} \mathrm{H}\right]$ glucose. At 10 -min intervals, after injection, the animals were killed and 1-2 $\mathrm{ml}$ whole blood were collected and added to an equal volume of $0.6 \mathrm{~N}$ perchloric acid (PCA). The perchloric acid extract $(0.5 \mathrm{ml})$ was added to ion exchange columns of overlaid equal bed volumes of anion (Bio-Rad AGl-X2) and cation (Amberlite IR-120) exchange resin as described by Peng et al. (13) which, on 
elution with water, gave a good separation of glucose from other metabolites. $\left[{ }^{14} \mathrm{C}\right]$ Glucose was estimated in the eluant by counting the ${ }^{14} \mathrm{C}$ radioactivity in the $\left[{ }^{3} \mathrm{H},{ }^{14} \mathrm{C}\right]$ glucose eluant peak with dual channel counting using a Beckman LS 355 liquid scintillation spectrometer. $\left[2{ }^{3} \mathrm{H}\right]$ Glucose was determined in PCA samples which had been dried under a stream of $\mathrm{N}_{2}$, rehydrated, and counted using dual channel liquid scintillation spectrometry.

The above dual ion exchange resin system was routinely used to remove ${ }^{14} \mathrm{C}$-labeled alanine, pyruvate, and lactate for the samples, while glucose was eluted, since label from lactate might be distributed among these other three carbon moieties in plasma. However, thin layer chromatography of blood PCA extracts on cellulose in butanol-water-pyridine $(1: 1: 1)$ and ethanol-ammoniawater $(80: 4: 16)$ gave only two detectable peaks of radioactivity, one with the same mobility as that of glucose and the other with that of L-lactate. $\left[{ }^{14} \mathrm{C}\right]$ Lactate was thus estimated in blood PCA extract samples by subtracting $\left[{ }^{14} \mathrm{C}\right]$ glucose from the total ${ }^{14} \mathrm{C}$ in the sample at any point in time. L-Lactate was estimated independently in these same extracts by the enzyme spectrophotometric method of Wieland (25).

\section{RESULTS}

\section{BLOOD GLUCOSE LEVELS}

The blood glucose levels in full term neonates showed an increase from a mean of $80.9 \pm 1.9 \mathrm{mg} / 100 \mathrm{ml}$ to $131 \pm 3 \mathrm{mg} / 100$ $\mathrm{ml}$ over the first $72 \mathrm{hr}$ of life with no value lower than $82 \mathrm{mg} / 100$ $\mathrm{ml}$ in between (Fig. 1). In contrast, the prematurely delivered neonates have a somewhat lower blood glucose at birth, $51.5 \pm 5.1$ $\mathrm{mg} / 100 \mathrm{ml}$, which falls to a minimum $19.7 \pm 8.4 \mathrm{mg} / 100 \mathrm{ml}$ at 2 $\mathrm{hr}$ of life to rise out of the hypoglycemic range by $12 \mathrm{hr}$ of life. During this period, the hepatic glycogen levels decreased dramatically in both groups, the net glycogen utilization being much greater in the full term animals. Significant recovery of hepatic glycogen reserves was also evident by three days of life in the full term animals (Fig. 2).

\section{ENZYMATIC ACTIVITY}

Whereas the activity of hepatic fructose-1,6-diphosphatase activity changed little over the first 3 days of life in either full term or premature animals (Fig. 3), the activity of glucose-6-phosphatase rose dramatically from $1.40 \pm 0.26 \mu \mathrm{mol} / \mathrm{min} / \mathrm{g}$ at birth to a maximum of $6.8 \pm 0.9 \mu \mathrm{mol} / \mathrm{min} / \mathrm{g}$ at $24 \mathrm{hr}$ in prematurely delivered animals, although again there was little significant change in activity in full term animals (Fig. 4). Little or no significant change was seen in the activity of mitochondrial phosphoenolpyruvate carboxykinase over the first 3 days of life in either full term or prematurely delivered guinea pigs (Fig. 5). Cytosolic phosphoenolpyruvate carboxykinase, on the other hand, has low activity at birth in both groups of neonates and shows a

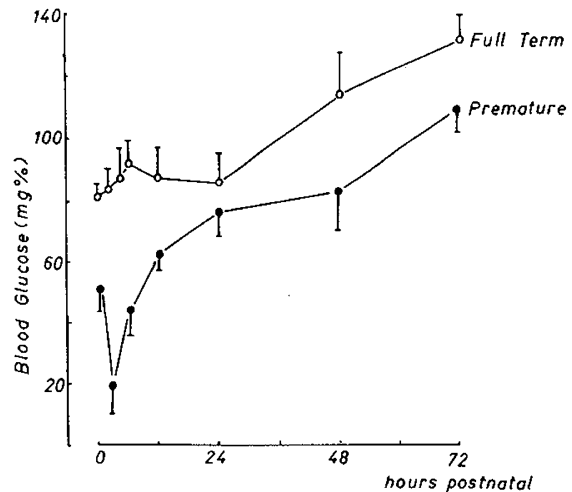

Fig. 1. Blood glucose levels in full term $(\mathrm{O}-\mathrm{O})$ and premature (- - guinea pigs over the first $72 \mathrm{hr}$ of life. Values are the means of six determinations \pm SEM

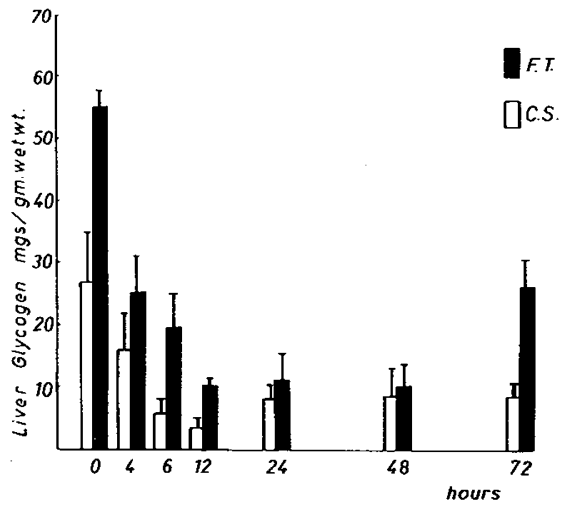

Fig. 2. Liver glycogen in full term and prematurely delivered guinea pigs over the first $72 \mathrm{hr}$ of life. Values are the means of six determinations \pm SEM. F.T.: full term; C.S.: cesarian section.

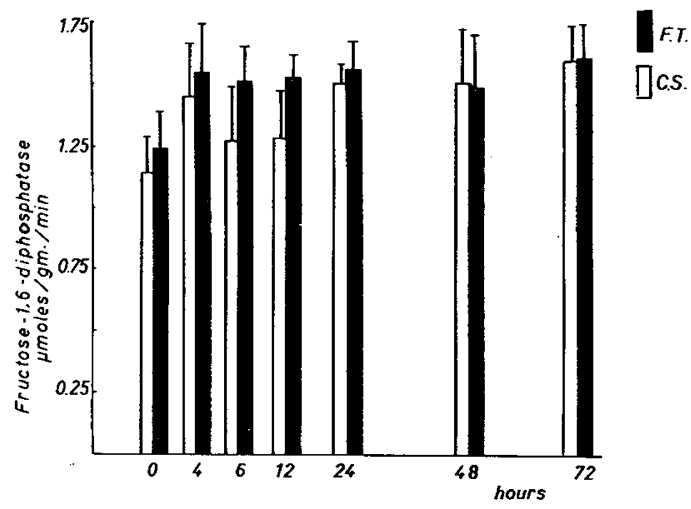

Fig. 3. Hepatic fructose-1,6-diphosphatase activity in full term and prematurely delivered guinea pigs over the first $72 \mathrm{hr}$ of life. Values are the means of six determinations \pm SEM. F.T.: full term; C.S.: cesarian section.

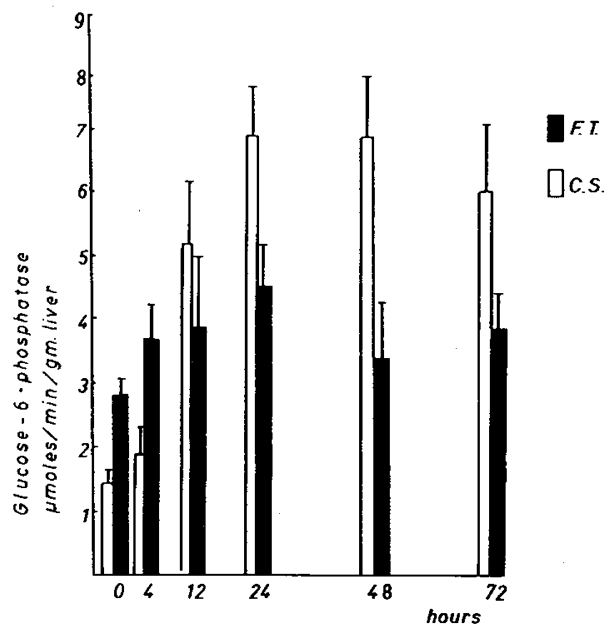

Fig. 4. Hepatic glucose-6-phosphatase activity in full term and prematurely delivered guinea pigs over the first $72 \mathrm{hr}$ of life. Values are the means of six determinations \pm SEM. F.T.: full term; C.S.: cesarian section.

steady increase over the first $24 \mathrm{hr}$ of life, the increase being more pronounced in the premature animals to give a value of $1.12 \pm 0.12$ at $24 \mathrm{hr}$ compared with $0.71 \pm 0.06 \mu \mathrm{mol} / \mathrm{min} / \mathrm{g}$ in full term animals (Fig. 6). Pyruvate carboxylase activity in prematurely delivered animals was some $53 \%$ of the activity seen in full term animals at birth and in both full term and premature animals underwent a steady rise in the first 3 days of life to achieve activities of $1.70 \pm 0.37$ in the premature compared with $2.43 \pm$ $0.05 \mu \mathrm{mol} / \mathrm{min} / \mathrm{g}$ in the full term animal (Fig. 7). Mitochon- 
drial protein was not significantly different in the two groups when expressed as milligrams per $\mathrm{g}$ liver.

\section{RADIOSOTOPE INCORPORATION EXPERIMENTS}

The injection of dual isotopic labels of $\mathrm{D}-\left[2-{ }^{3} \mathrm{H}\right]$ glucose and $\mathrm{L}-\left[U-{ }^{14} \mathrm{C}\right]$ lactate was designed to give an estimate of the rate of incorporation of lactate into glucose. Figure 8 shows the result of such an experiment performed with prematurely delivered animals 5 min postnatally and the combined results of four such experiments for each time period shown in Table 1. Extrapolation of the $\left[{ }^{3} \mathrm{H}\right]$ glucose specific activity to zero time on a semilogarithmic plot $(23,24,26)$ gives a mean glucose space of $60.8 \mathrm{ml} / 100 \mathrm{~g}$ body weight. By monitoring the $\left[{ }^{14} \mathrm{C}\right]$ glucose specific activity with time and knowing the glucose space it was calculated that the peak incorporation of lactate into glucose at $20 \mathrm{~min}$ represented $15.5 \%$ of the total $\left.{ }^{14} \mathrm{C}\right]$ lactate injected at time zero. This figure rose to $32.4 \%$ at 3 days of life (Table 1). In contrast, the full term animals showed a high $\left[{ }^{14} \mathrm{C}\right]$ lactate incorporation into glucose at birth which was virtually unchanged at 3 days of life. Glucose space decreased by some $33 \%$ in both full term and premature animals by 3 days of life. Incorporation of $\left[{ }^{14} \mathrm{C}\right]$ lactate into hepatic

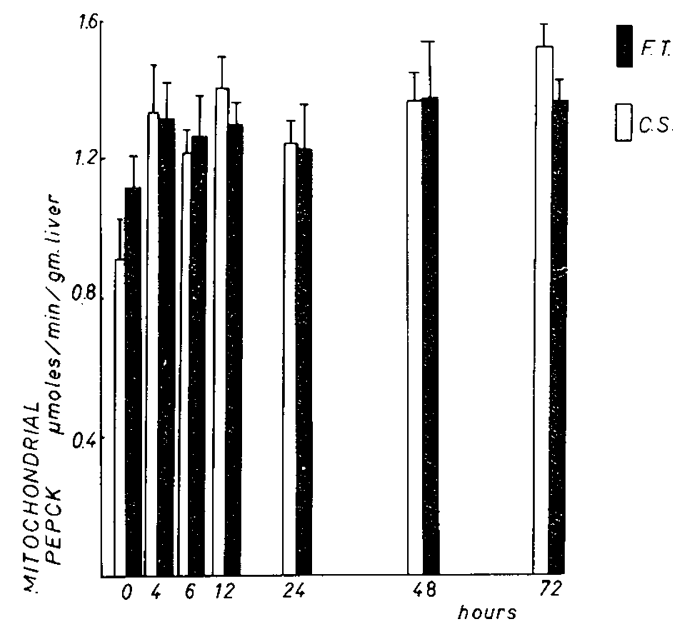

Fig. 5. Hepatic mitochondrial phosphoenolpyruvate carboxykinase activity in full term and prematurely delivered guinea pigs over the first $72 \mathrm{hr}$ of life. Values are the means of six determinations \pm SEM. F.T.: full term; C.S. cesarian section. PEPCK: phosphoenolpyruvate carboxykinase.

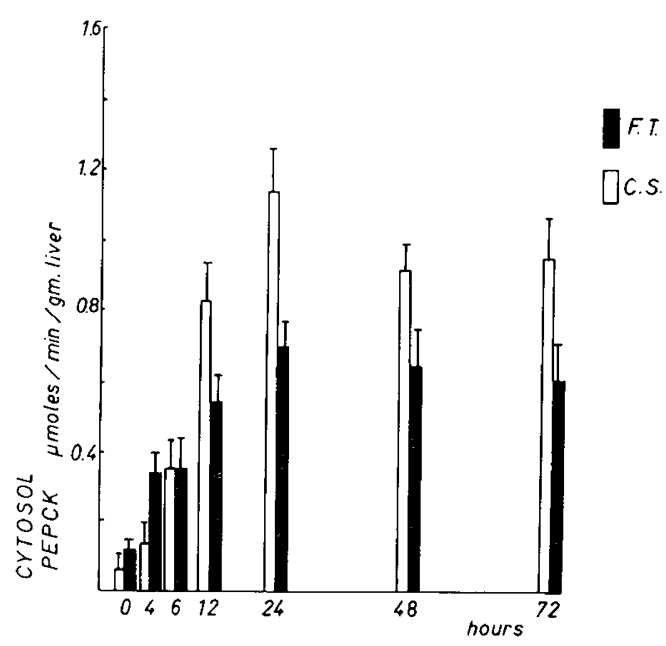

Fig. 6. Hepatic cytosolic phosphoenolpyruvate carboxykinase activity in full term and prematurely delivered guinea pigs over the first $72 \mathrm{hr}$ of life. Values are the means of six determinations \pm SEM. F.T.: full term; C.S.: cesarian section. PEPCK: phosphoenolpyruvate carboxykinase.

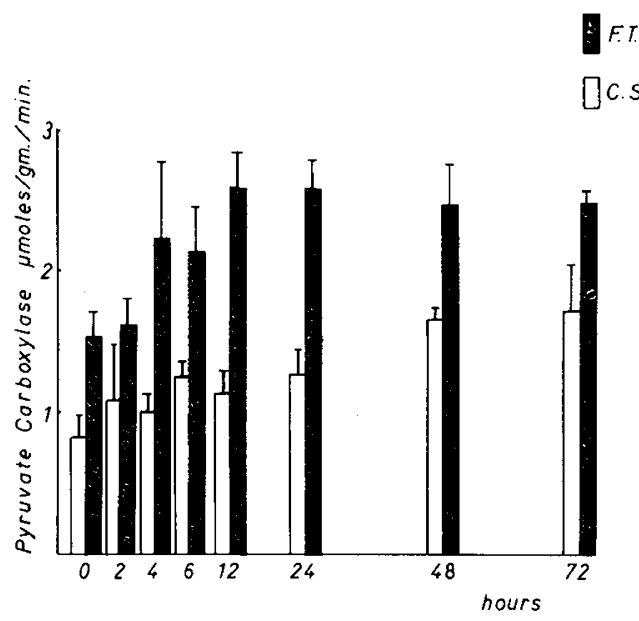

Fig. 7. Hepatic pyruvate carboxylase activity in full term and prematurely delivered guinea pigs over the first $72 \mathrm{hr}$ of life. Values are the means of six determinations \pm SEM. F.T.: full term; C.S.: cesarian section.

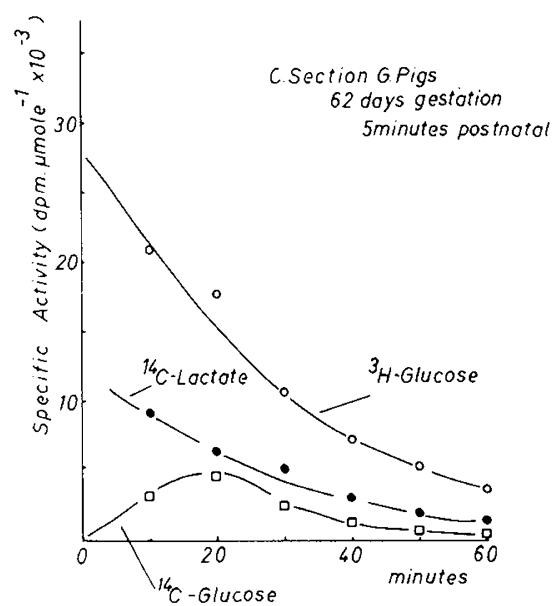

Fig. 8. Time course of specific activity of $\left[{ }^{14} \mathrm{C}\right]$ lactate $\left[{ }^{3} \mathrm{H}\right]$ glucose $(\mathrm{O}-\mathrm{O})$, and $\left[{ }^{14} \mathrm{C}\right]$ glucose $(\square-\square)$ after injection of $\left[U-{ }^{14} \mathrm{C}\right]$ lactate and $\left[2-{ }^{3} \mathrm{H}\right]$ glucose in newborn prematurely delivered guinea pigs. Experiments were carried out as described under Methods.

glycogen was initially measured in these experiments but found to constitute less than $1 \%$ of the total $\left[{ }^{14} \mathrm{C}\right]$ lactate administered.

\section{DISCUSSION}

Hypoglycemia in the newborn period in the human population of neonates is encountered most commonly among those individuals having a low birth weight due to premature delivery or interuterine growth retardation (6). In contrast, the full term newborn laboratory rat develops hypoglycemia over the first few hours of life, and this has been variously attributed to hypoxia (12) or to the low activities of the key gluconeogenic enzymes in the liver, especially the enzyme phosphoenolpyruvate carboxykinase $(2,3,9)$. In the newborn guinea pig neonatal hypoglycemia was seen only in the prematurely delivered animals. The activities of gluconeogenic enzymes at birth show significant differences only in glucose-6-phosphatase and in pyruvate carboxylase, which, especially in the case of the latter enzyme, may compromise the adequate working of the gluconeogenic pathway. The difference seen in the available reserves of hepatic glycogen between premature and full term animals may have some bearing on the hypoglycemic status of the former group. Hepatic glycogen in the rat falls rapidly after birth (9) as it was observed to do in the guinea pig both in the full term and premature animals. However, calculation of the amount of glucose utilized during the first $4 \mathrm{hr}$ of life from the available glycogen stores gives a rate of 2.70 $\mu \mathrm{mol} / \mathrm{min} / 100 \mathrm{~g}$ body weight for the full term but only 1.15 
Table 1. $\left[{ }^{3} \mathrm{H}\right]$ Glucose space, blood lactate, and $\left[{ }^{14} \mathrm{C}\right]$ lactate incorporation into glucose in newborn guinea pigs ${ }^{1}$

\begin{tabular}{|c|c|c|c|c|}
\hline & \multicolumn{2}{|c|}{ Cesarian section } & \multicolumn{2}{|c|}{ Full term } \\
\hline & At birth & 3 days & At birth & 3 days \\
\hline Glucose space (ml/100 g body weight) & $60.8 \pm 2.8$ & $40.6 \pm 3.1$ & $69.0 \pm 2.4$ & $46.0 \pm 3.1$ \\
\hline Blood lactate $(\mathrm{mM})$ & $3.19 \pm 0.39$ & $2.76 \pm 0.28$ & $3.60 \pm 0.58$ & $2.34 \pm 0.29$ \\
\hline Peak $\left[{ }^{14} \mathrm{C}\right]$ lactate incorporation (\%) into glucose of total injected & $15.5 \pm 2.1$ & $32.4 \pm 3.3$ & $31.6 \pm 3.2$ & $35.2 \pm 4.1$ \\
\hline
\end{tabular}

${ }^{1}$ Each experiment was carried out as described for Figure 8, using guinea pigs at birth or at 3 days of age. The results shown are the means of results from four experiments \pm SEM.

$\mu \mathrm{mol} / \mathrm{min} / 100 \mathrm{~g}$ body weight for the premature animals. This must be a contributory factor to the hypoglycemia seen in the prematurely delivered animals. Assay of total phosphorylase activity at birth in these two groups at birth showed no significant difference, although we were not able to measure in this series of experiments the proportion of active to inactive phosphorylase.

The possibility that hypoglycemia could result from the low activity of cytosolic phosphoenolpyruvate carboxykinase seen at birth in the newborn rat and the applicability of this argument to the situation in man has been a subject for some comment $(1,4$, 17). The fact that the mitochondrial complement of phosphoenolpyruvate carboxykinase shows adequate activity at birth in the guinea pig $(1,17)$ may given reason to suppose the low cytosolic phosphoenolpyruvate carboxykinase in the animal at birth does not compromise the activity of the gluconeogenic pathway. Since the disposition of phosphoenolpyruvate carboxykinase is similar in man and guinea pig, being equally active in both cytosolic and mitochondrial compartments in the adult, the guinea pig may be a better model for the human neonatal situation. Our results here suggest that in the immediate postnatal period in which hypoglycemia is experienced by the premature animals, the phosphoenolpyruvate carboxykinase activities differ little between the two groups until $12 \mathrm{hr}$ postpartum, when the prematurely delivered animals show a significantly greater activity than the full term animals, possibly because of induction by a combined high glucagon to insulin ratio and cortisol level experienced during the period of hypoglycemia $(8,10)$.

The information from the radioisotope experiments could possibly give information about the glucose space, the rate of glucose utilization, and the rate of lactate incorporation into glucose. The rate of detritiation of $\left[2-{ }^{3} \mathrm{H}\right]$ glucose gives a measurement of the rate of glucose utilization since any metabolism of glucose as far as hexose 6-phosphate isomerase leads to detritiation. However, calculated rates may seriously overestimate the actual glucose utilization rate because of "futile cycling" which leads to detritiation in the liver and kidney $(5,11)$. Both full term and premature animals show very large glucose spaces at birth compared with that of 3 days of life, a situation which is unexpected as glucose levels are generally higher at the 3-day period. Stimulation of glucose transport and utilization by hypoxia as described by Randle (15) may be responsible for this.

The peak incorporation of $\left[{ }^{14} \mathrm{C}\right]$ lactate into the glucose pool is lower at birth in the premature animals (15.5\%) compared with the full term animals $(31.6 \%)$, there being little difference at 3 days of life. This contrasts with data from the rat which shows very little $\left[{ }^{14} \mathrm{C}\right]$ lactate incorporation into glucose in the first few hours of life $(<3 \%)(12,23,24)$. We conclude from our studies that the hypoglycemia seen in prematurely delivered animals stems from (I) an insufficient store of hepatic glycogen and (2) a slower rate of functioning of the gluconeogenic pathway in these animals. One possible problem with this model is the unquantitated effect which alimentation may be having on glycemic status in these animals since we cannot be sure that premature animals receive adequate milk from their foster mothers. Experiments now under way to examine the effect of starvation on full term neonates indicates that food deprivation has little effect on glycemic status in the first
$24 \mathrm{hr}$ of life. It is therefore unlikely that differential alimentation has a great effect on glycemic status in this experimental model.

\section{REFERENCES AND NOTES}

1. Arinze, I. J.: On the development of phosphoenolpyruvate carboxykinase and gluconeogenesis in guinea-pig liver. Biochem. Biophys. Res. Commun., 65: 184 (1975).

2. Ballard, F. J.: Kinetic studies with cytosol and mitochondrial phosphoenolpyruvate carboxykinase. Biochem. J., 120: 809 (1970).

3. Ballard, F. J.: Development of gluconeogenesis in rat liver. Biochem. J., 124: 265 (1971).

4. Chlebowski, R. T., and Adam, P.: Glucose production in the newborn dog. II Evaluation of autonomic and enzymatic control in the isolated perfused canine liver. Pediat. Res., 9: 821 (1975).

5. Clark, D. C., Rognstad, R., and Katz, J.: Isotopic evidence for futile cycles in liver cells. Biochem. Biophys. Res. Commun., 54: 1141 (1973).

6. Cornblath, M., Ganzon, A. F., Nicoiopoulos, D., Beans, G. S., Hollander, R. J., Gordon, M. H., and Gordon, H. H.: Symptomatic neonatal hypoglycaemia: Studies of carbohydrate metabolism in the newborn infant. Pediatrics, 27: 378 (1961).

7. Crabtree, B., Higgins, S. J., and Newsholme, E. A.: The activities of pyruvate carboxylase, phosphoenolpyruvate carboxykinase and fructose 1,6-diphosphatase in muscles from vertebrates and invertebrates. Biochem. J., 130: 391 (1972).

8. Girard, J. R., Caquet, D., Bal, D., and Guillet, I.: Control of rat liver phosphorylase, glucose-6-phosphatase and phosphoenolpyruvate carboxykinase activities by insulin and glucagon during the perinatal period. Enzyme, 15: 272 (1973).

9. Girard, J. R., Cuendet, G. S., Marliss, E. B., Kervan, A., Rieutort, M., and Absan, R.: Fuels, hormones and liver metabolism at term and during the early postnatal period in the rat. J. Clin. Invest., 52: 3190 (1973).

10. Gunn, J. M., Hanson, R. W., Meyuhas, O., Reshef, L., and Ballard, F. J.: Glucocorticoids and the regulation of phosphoenolpyruvate carboxykinase in the rat. Biochem. J., 150: 195 (1975).

11. Katz, J., Dunn, A., Chenoweth, M., and Golden, S.: Determination of resynthesis, recycling and body mass of glucose in rats and rabbits in vivo with ${ }^{3} \mathrm{H}$ - and ${ }^{14} \mathrm{C}$-labelled glucose. Biochem. J., 142: 171 (1974).

12. Pearce, P. H., Buirchell, B. J., Weaver, P. K., and Oliver, I. T.: The development of phosphoenolpyruvate carboxykinase and gluconeogenesis in neonatal rats. Biol. Neonate, 24: 320 (1974).

13. Peng, Y., Brook, M., Elson, C., and Shrago, E.: Contribution of the cytosol and mitochondrial pathways to phosphoenolpyruvate formation during gluconeogenesis. J. Nutr., 103: 1489 (1973).

14. Pontremoli, S.: Fructose 1,6-diphosphatase. In: S. P. Colowick and N. O. Kaplan: Methods in Enzymology, Vol. IX, p. 625 (Academic Press, New York, 1966).

15. Randle, P. J.: Fuel and power in the control of carbohydrate metabolism in mammalian muscle. Symp. Soc. Exp. Biol., 18: 129 (1964).

16. Robinson, B. H.: 3-Mercaptopicolinic acid, a preferential inhibitor of the cytosolic phosphoenolpyruvate carboxykinase. Fed. Eur. Biochem. Soc. Lett., 58: 12 (1975).

17. Robinson, B. H.: Development of gluconeogenic enzymes in the newborn guinea-pig. Biol. Neonate 29: 48 (1976).

18. Roobol, A., and Alteyne, G. A. O.: Regulation of renal gluconeogenesis by calcium ions, hormones and cyclic $3^{\prime} 5^{\prime}$-adenosine monophosphate. Biochem. J. 134: 157 (1973).

19. Slein, M. N.: Determination of glucose with hexokinase. In: H. U. Bergmeyer: Methods in Enzymatic Analysis, p. 117 (Weinheim Verlag Chemia, Germany, 1963).

20. Soling, H. D., Williams, B., Kleineke, J., and Gelhoff, M.: Regulation of gluconeogenesis in the guinea-pig liver. Eur. J. Biochem., 16: 289 (1970).

21. Swanson, M.: Glucose-6-phosphatase from liver. In: S. P. Colowick and N. O. Kaplan: Methods in Enzymology, Vol. II, p. 541 (Academic Press, New York, 1955).

22. Yeung, D., and Oliver, 1 .: Development of gluconeogenesis in the neonatal rat liver: Effect of premature delivery. Biochem. J., 103: 744 (1967).

23. Vernon, R. G., and Walker D. G.: Gluconeogenesis in the developing rat. Biochem. J., 127: 521 (1972)

24. Vernon, R. G., and Walker. D. G.: Gluconeogenesis in the developing rat. 
Biochem. J., 127: 531 (1972).

25. Wieland, $\mathrm{O}: \mathrm{L}(+)$ Lactate determination with lactate dehydrogenase from yeast In: H. U. Bergmeyer: Methods of Enzymatic Analysis, p. 271 (Academic Press, New York, 1965)

26. Wrenshall, G. A.: The kinetics of isotope turnover in mammalian systems. Can.

J. Biochem. Physiol., 33: 909 (1955).
27. We thank the Canadian Medical Research Council (Grant MRC MA5473) and the Weston Foundation for financial support.

28. Requests for reprints should be addressed to: B. H. Robinson, M.D., Research Institute, The Hospital for Sick Children, 555 University Ave., Toronto, Ontario M5G IX8 (Canada).

29. Accepted for publication May 4, 1976

\title{
The Adaptation of the Fetal Red Cells of Newborn Lambs to Extrauterine Life: The Role of 2,3-Diphosphoglycerate and Adult Hemoglobin
}

\author{
H. BARD, (12) J.-C. FOURON, A. M. GROTHE, M. A. SOUKINI, AND A. CORNET \\ Perinatal Service and Research Center of Hôpital Sainte-Justine, Department of Pediatrics, University of Montreal, \\ Montreal, Quebec, Canada
}

\section{Extract}

The purpose of this study was to determine the interrelationship of the rise and fall of 2,3-diphosphoglycerate (DPG) with the increase in adult hemoglobin and the decrease in red cell oxygen hemoglobin affinity after birth in normal lambs. It was found that the mean maximum DPG level was $26.71 \pm 4.98 \mathrm{~mol} / \mathrm{g} \mathrm{Hb}$ at $7.5 \pm$ 1.1 days. At the same time the mean $P_{50}$ and adult hemoglobin level was $27.0 \neq 1.4 \mathrm{~mm} \mathrm{Hg}$ and $31.1 \pm 11.1 \%$, respectively. In the individual lambs, the level of their maximum DPG correlated inversely with the amount of adult hemoglobin $(r-\mathbf{0 . 7 7}, P<0.05)$. Once the DPG began to decrease, there was an inverse correlation between the DPG and the adult hemoglobin present in the red cell $(r=0.68, P<0.001)$. It appeared that the rise in DPG postanatally is only a compensatory mechanism until an adequate amount of adult hemoglobin is present. This fact was borne out by the second part of the study in which exchange transfusions with adult red cells were performed on five newborn lambs during the first $24 \mathrm{hr}$ after birth and aborted the rise in DPG.

\section{Speculation}

The adaptation from the in utero to the extrauterine environment requires a rapid reduction in red cell oxygen affinity. The decrease in oxygen affinity is achieved by a transitory postnatal increase in intraerythrocyte DPG.

During in utero life the role of high affinity fetal blood is to provide a physiologic advantage that facilitates oxygen transport across the placenta. After birth a more efficient extraction of oxygen by the tissues is needed which is accomplished by the lowered affinity of adult blood.

It was Battaglia et al. (1) who demonstrated in newborn lambs that $\mathrm{pH}$ across the red cell and DPG concentration within the red cell both increase as there is a marked decrease in oxygen affinity compared with fetal blood. Similar postnatal changes in human red cells, although much less pronounced, have been described by Versmold et al. (6).
In order to further the understanding of the great transitory increase in DPG during the first weeks of life in the newborn lamb, the following studies were planned: $(l)$ to follow sequentially in the same animal the rise and fall of DPG, the percentage of adult and fetal hemoglobin along with changes of the oxygen dissociation curve; and (2) to repeat the above study after having provided the newborn animal with an adult oxygen hemoglobin dissociation curve within hours after birth.

\section{MATERIALS AND METHODS}

Mixed breed newborn lambs (Dorset and Suffolk) were used in this study. The experiment was divided up into two sections. The first part was to sample postnatally at 3- to 5 day intervals via the jugular vein normal newborn lambs and to correlate their erythrocyte DPG, $\mathrm{P}_{50}$, and proportion of adult and fetal hemoglobin with postnatal age.

Erythrocyte DPG concentration was determined on fresh heparinized blood according to the method of Keitt (5) and expressed as micromoles per $\mathrm{g} \mathrm{Hb}$. The reagents were obtained from Sigma Chemical Company (7).

The $\mathrm{P}_{50}$ was determined by gas mixing tonometry using a IL 217 blood gas laboratory (8) (213 blood gas analyzer, 237 tonometer, 208 gas mixing system, and 182 co-oximeter). The $\mathrm{P}_{50}$ values were

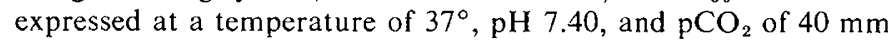
$\mathrm{Hg}$.

Samples of fresh blood were equilibrated in a tonometer for 30 min at $37^{\circ}$ with gas mixtures containing $40 \mathrm{~mm} \mathrm{Hg}( \pm 0.05 \mathrm{~mm}$ $\mathrm{Hg}) \mathrm{CO}_{2}$ and varying proportions of $\mathrm{O}_{2}$ and $\mathrm{N}_{2}$. The tonometer permitted an equilibration and sampling of successive aliquots of blood at different $\mathrm{O}_{2}$ tensons. Measurement of $\mathrm{O}_{2}$ saturation, $\mathrm{pH}$, and $\mathrm{PO}_{2}$ provided the information for plotting the $\mathrm{O}_{2}$ dissociation curve and $\mathrm{P}_{50} . \mathrm{PO}_{2}$ was always converted to $\mathrm{pH} 7.4$ using a Bohr effect of 0.46 (4).

The oxygen saturation obtained by use of the co-oximeter was checked by determining the oxygen contents of blood samples equilibrated in the tonometer by use of the $\mathrm{Lex}-\mathrm{O}_{2}$-Con (9).

The percentage of adult and fetal hemoglobin was obtained by 